\title{
USING GRAPHIC ORGANIZER TO IMPROVE THE STUDENTS' READING COMPREHENSION ACHIEVEMENT
}

\author{
Prihatin Puji Astuti \\ Universitas Pamulang \\ dosen01119@unpam.ac.id
}

\begin{abstract}
This study investigated the use of a graphic organizer reading strategy in improving the students' reading comprehension achievement. It was aimed to find out to what extend the improvement of the students reading comprehension after being treated using the graphic organizer strategy. This research also wanted to check the differences in the result between the class which used the graphic organizer and the class which did not apply a specific reading strategy. This study was conducted at the grade 11 students of SMK Sasmita Jaya Tangerang Selatan. This research administered cluster random sampling in taking samples and decided two classes as the same samples. One class was treated using a graphic organizer and the other class was not treated using any specific kind of strategy or conventional strategy. The method of this research was quantitative research under quasi-experimental research. A quasi-experimental design was used to know the result after specific treatment was applied. After collecting the data, then it was analyzed using SPSS. Based on the result of the data analysis, it was found that applying the Graphic Organizer reading strategy in reading lessons could improve students' reading comprehension achievement.
\end{abstract}

Keywords: reading comprehension, graphic organizer, strategy, quasi experiment

\section{INTRODUCTION}

The goal of reading is comprehension. Comprehension is the process of making sense of words, sentences, and text. Comprehension is a very essential thing in reading because it is a way to get the required information of the text. We not only read aloud but also construct our comprehension of the text. Because of that, the student must have a good ability on how to comprehend well. A good ability cannot be achieved instantly. The students should be trained to be able to participate actively in the learning process so that later they can think critically. Therefore, the use of various strategies in teaching reading is very useful in reading comprehension.

Based on the pre-observation that the researcher had done in SMK Sasmita Jaya, not all students were good at reading comprehension. The researcher concluded it happened because of some factors, both from the students and teachers. The student indicated had lack of vocabulary since they found some difficulties in finding the main idea in the reading text given by the teacher. They found some unfamiliar words that made them confused to guess the meaning of the word in 
one paragraph. The researcher found that the student didn't use the reading strategy in finding the main ideas, most of the whole paragraph. They did not know how to find the main ideas fast.

The problems came also from the teacher's side. Based on the pre-observation, in the learning process, the teacher still used conventional strategy in teaching reading. They asked the student to read and understand a text. If they found difficult words, they could ask the teacher. After reading, the teacher asked one or more students to come in front of the class to read a text loudly then the teacher gave a question about the text. This learning condition might make the student was not interested to learn, they got bored.

The teacher tended to use the textbook provided by the school and ignored the learner's style. The teacher applied one teaching technique and do not try to practice other techniques. It caused the students' reading comprehension not increase maximally. Therefore, to enhance the students' achievement in reading comprehension, they needed a good strategy that could help them to comprehend reading text.

The important factor of reading comprehension was a reading strategy. To enhance the students' achievement in reading comprehension, they needed a good strategy that could help them to comprehend reading text. The researcher would apply a graphic organizer and compare with other or conventional strategy. The graphic organizer was a good strategy that could improve students' reading comprehension. It is a visual device such as a diagram, chart, outline that can help the student to construct and organize what they read. In implementing a graphic organizer, the student could depict a graphic by themselves and identify the information in the graphic. So, the information of the text would be easily understood and remembered. Besides that, the student would have a good ability on how to organize text.

The researcher identified the following problems: (1) Students were lack of vocabulary, when they read a text, (2) The students' reading comprehension was not good, (3) Learning strategy was not effective in improving students' reading comprehension achievement, (4)Students were lack of interest to read, (5) Students' motivation in learning English was law, (6)The teacher rarely asked the student to get exposure and practice,

The objectives of the research were: (1) to investigate the significant difference between students who use a graphic organizer and those who use conventional strategic reading in students' reading comprehension, (2) To investigate the significant improvement of the students who apply graphic organizer.

To sum up, in this study, the researcher applied a graphic organizer to improve students reading comprehension. The researcher had an assumption that graphic organizer provides features which is suitable with the characteristic of the students at the $11^{\text {th }}$ grade of SMK Sasmita Jaya. This research entitled "USING GRAPHIC ORGANIZER TO INCREASE STUDENTS' READING COMPREHENSION" was used to investigated the effect of the strategy in improving the student's reading comprehension achievement.

\section{REVIEW OF LITERATURE}

The researcher described some previous studies in improving students' reading comprehension through a graphic organizer. Firstly, the research about the effect of graphic organizer strategy by Premalatah and Sam (2013) who carried out a study investigated the use of a graphic organizer to improve reading comprehension skill for the middle school of ESL Students. The finding of the research showed that graphic organizer is effective to be used in answering questions as like: identifying the mind idea, finding the supporting detail, dealing with vocabulary, fact, opinion, and making an inference.

Lexeme : Journal of Linguistics and Applied Linguistics, Vol 2(2), $2020 \mid$ 
In addition, Bethun \& Wood (2013) made a study on the effect of WH- question graphic organizer on the reading comprehension skills of students with an autism spectrum disorder. The data were gathered from three elementary age-students with an autism spectrum disorder. The result indicated all three students were able to demonstrate generalization to their reading program worksheet administered during regular reading instruction.

Furthermore, Lynn and Miranda (2011) conducted the research entitled the effect of graphic organizers on the reading comprehension of English language learner with a learning disability. The study focused on finding out the effect of graphics on the reading comprehension of English language learners with a learning disability in a Honolulu middle school as shown through the participant's recall and application of rational knowledge from social studies content material. The result indicated that the study had positive effects on the female of disability learning. Her ability to content knowledge is higher $35 \%$ from pre-test to post-test. Two participants who learning without disabilities have positive effects also. They improved their reading comprehension through their improvement in content knowledge. In the end, the researcher concluded that graphic organizers were an effective comprehension intervention for English language learners with or without disabilities.

Snow (2002) defines reading comprehension as "the process of simultaneously extracting and constructing meaning through interaction and involvement with written language". Furthermore Harvey (2006) states "reading comprehension is which the reader has to understand what they read". Meanwhile Snow. C, \& Chair (2002) defined "reading comprehension as the process of simultaneously extracting and constructing meaning through interaction and involvement with written language". Similar definition, based on the book entitled "Knowledge for Teaching Reading Comprehension: Mapping Terrain" stated, reading comprehension is the process of constructing and extracting meaning. (Scoot, 2009). Moreover, Lehr, F, Osborn, J, \& Hiebert, E (2005) mentioned "reading comprehension is as a multidimensional process that involved factors related to the reader, the text, and the activity".

Based on the theories above, the researcher concluded that reading comprehension is the ability to comprehend what the people read. It means that the readers should be active to interpret the idea of the text and then integrate the new information with prior knowledge. It was a complex process that involves thinking, decoding, and integrating the information. Reader, text, and activity were also involved in the reading comprehension process. So, it was not easy to do.

A graphic organizer is one of the strategies used in reading comprehension. The graphic organizer can improve students reading comprehension by using visual tools. In the process of reading comprehension, the student will create an appropriate schema that suitable for the text. By applying the graphic organizer, the information of the text will be easier to be identified and remembered. The students can understand what text about easily. Then the purpose of reading as comprehension could be reached.

According to Grabe (2009), "graphic organizer creates an important combination of text structure awareness, main idea recognition, and imagery". Applying a graphic organizer to organize the text information leads to improve recall information and significantly better comprehension. Additionally, in a book entitled Graphic Organizer as a reading Strategy: Research Findings and Issues state that graphic organizer as a reading strategy is used both in teaching and learning of language and in content areas, like science and social studies. The graphic organizer is to boost compression skill in target subject area, so the students' reading comprehension skill will improve and can contribute to the acquisition of target language (Polyxeni \& Maria 2012). 
Based on the theory above, it can be summarized that a graphic organizer is a visual device such as schema, chart, outline, or diagram in arranging the information of the text. The student can organize their ideas and break down into the schema, so the information of the text will be understood easily. It is a good way to be applied in teaching reading comprehension, consequently, the student can improve their reading comprehension.

Furthermore, based on the dissertation entitled "The Effect of Graphic on EFL Reading Comprehension and Attitude Toward Reading English", it is explained that the procedure of graphic organizer refers to pre-reading activity, during reading activity, and post-reading activity. Pre-reading activity is the process to link the prior knowledge to the new information. The teacher presents a graphic organizer as an overview and introduces key vocabulary related to the topic. While in pre-reading activity, the teacher asks the student to find the key point of the text and note it in the blank graphic organizer. In post-reading activities the teacher discussed with the students any problems found and revised it (Chiang CL 2005)

It is concluded that the procedure of graphic organizer refers to pre-reading activities, where the teachers choose the topic and explain what graphic organizer is, and how to use it. During reading activities, the teacher asks the student to organize the information of the text, by notetaking in a blank of the graphic. After that, the students share the information of the text. As postreading activities, the teacher concludes the material.

\section{METHOD}

The researcher used the quantitative research method under an experimental study. According to Frenkel \& Walen (2000), "an experimental study, researchers look at the effect of at least one independent variable on one or more dependent variable". In this study, the researcher applied two independent variables and one dependent variable. Reading strategy was determined as an independent variable and reading comprehension achievement as a dependent variable.

This study was designed as a true experimental design under pre-test and post test group design. The experimental study had the purpose to investigate the effect of two different treatments. The first treatment was a graphic organizer strategy and the second was a conventional reading strategy. The treatment began by explaining the characteristics of the strategies. It had a purpose to make the student become familiar with the strategy used. After that, the teacher implemented the strategy in the classroom. The researcher only took two classes by using cluster random sampling. Cluster random sampling is more effective with larger numbers of groups or clusters. Frankel and Wallen state "a cluster random sample is one obtained by using groups as the sampling unit rather than individuals". In this study, the researcher took one class as the treatment group of the graphic organizer strategy and another class as the comparison group of conventional reading strategy. The population of this research was the entire students of grade 11 of SMK Sasmita Jaya. . There are six parallel classes at grade 11 which consists of 20-30 Students.

\section{FINDINGS AND DISCUSSION Finding}

The researcher tested two hypotheses by analyzing the data of pre-test and post-test on reading comprehension for both treatment class and control class. In analyzing the data the researcher used a paired sample t-test to answer the research question number one and independent sample test to answer the research question number two on SPSS 20. And the result was analyzed as follows: The effect of Graphic Organizer reading strategy on reading comprehension achievement for grade XII students of SMK Sasmita Jaya 2 Pamulang

Lexeme : Journal of Linguistics and Applied Linguistics, Vol 2(2), 2020 | 


\section{Table 1}

Paired Samples Test

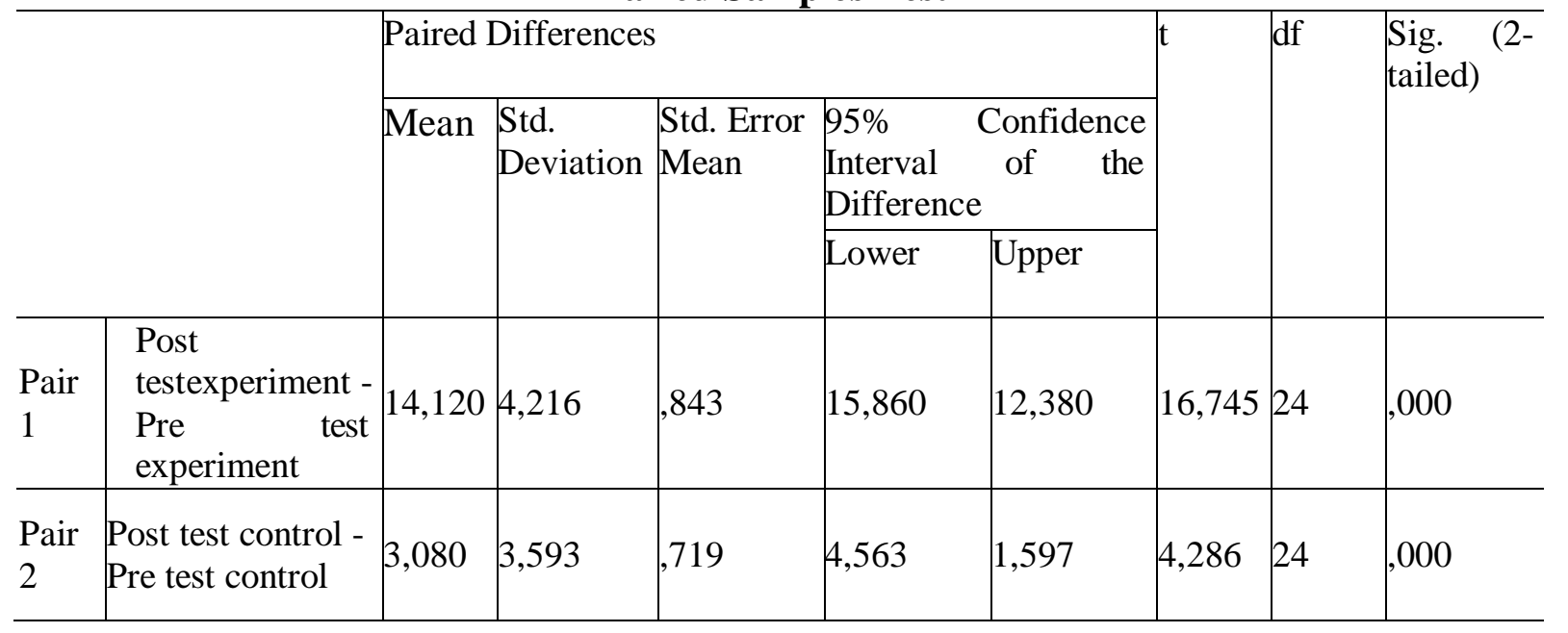

Based on Table 1: output pair 1 shows that the sig value is 0.000 which is under $\alpha=0.05$. It means that $\mathrm{H}_{-} 0$ is rejected and $\mathrm{H}_{-} 1$ is accepted. Meanwhile from the critical value approach, the data shows that the $\mathrm{t}$-value is 16,746 which is higher than $\mathrm{t}$-table $=1.711$. It emphasizes the assumption that H_0 is rejected and H_1 is accepted. From the mean score, the p-value approach and the critical value approach, it could be interpreted that there was a significant improvement in reading comprehension achievement after the treatment of the Graphic Organizer reading strategy applied.

The SPSS analysis was used to know the result if there was a significant difference between the experiment class and control class after being applied with the certain strategy, graphic organizer reading strategy, and the class that was not treated using certain strategy. In the other words, the other class was treated using a conventional strategy. The table below showed The significant differences between the Graphic Organizer Reading strategy (experiment class) and conventional reading strategies (control class) in their effects on students' reading comprehension achievement.

The data has obtained that sig. 0.000 value is lower than 0.05 and $F$ statistic (2.362) is lower than $\mathrm{F} \alpha$ (F table) 3.403. This emphasizes the result that $\mathrm{H} \_1$ is accepted and $\mathrm{H} \_0$ is rejected. So the conclusion of the data is that there is a significant increase in the learning achievement of students' reading comprehension after being treated using the Graphic Organizer reading strategy. Moreover, descriptive statistics clearly state the difference. The data show that the maximum posttest score of the experimental class is 85 while the maximum post-test score of the control class is 75. The mean score of the experimental class is 72.64 which is higher than the average score of the experimental class. control class (61.04). This shows that there is a difference of about 11.04 points between the two classes.

\section{Discussion}

There are two main points that are important results of this research; (1) the influence of the Graphic Organizer reading strategy in improving students 'reading comprehension, (2) the difference between Graphic Organizer reading strategies and conventional strategies in improving students' reading comprehension learning outcomes,

Lexeme : Journal of Linguistics and Applied Linguistics, Vol 2(2), $2020 \mid$ 
In connection with the first research question, whether or not there was a significant increase in reading comprehension achievement of the XII grade students of SMK Sasmita Jaya who were taught using the Graphic Organizer reading strategy. The results showed that there was a significant increase in the learning outcomes of students' reading comprehension after being given the Graphic Organizer reading strategy treatment. This is evidenced by the results of the SPSS analysis in this study which show that the sig value of 0.000 is lower than $\alpha=0.05$ and the $\mathrm{t}$-value of 16.745 is higher than $\mathrm{t}$ table $=1.711$. This means that $\mathrm{H} \_0$ is rejected and $\mathrm{H} \_1$ is accepted. The interpretation is that there is a significant increase in the learning outcomes of students' reading comprehension after being given treatment using the Graphic Organizer reading strategy.

The findings of this study are linear with previous research conducted by several researchers such as Premalatah and Sam (2013) who conducted research to investigate the use of graphic organizers to improve reading comprehension skills in ESL junior high school students. The results showed that the graphic organizer was effectively used in answering questions such as: identifying ideas, finding supporting detail, dealing with vocabulary, fact, and opinion, and making inferences.

Moreover, Bethun \& Wood (2013) who made a study on the effect of WH- question graphic organizer on reading comprehension skill of student with an autism spectrum disorder. The result indicated all three students were able to demonstrate generalization to their reading program worksheet administered during regular reading instruction. Lynn and Miranda (2011) conducted the research entitled the effect of graphic organizer on the reading comprehension of English language learners with a learning disability. The result indicated that the study had a positive effect on the female of disability learning. Her ability to content knowledge is higher $35 \%$ from pre-test to post-test. They improved their reading comprehension through their improvement in content knowledge. In the end, the researcher concluded that graphic organizers were an effective comprehension intervention for English language learners with or without disabilities.

In Graphic Organizer, the students were supposed to activate their skill and their ability and grabbing the important point by making graphics. The graphic would ease them to get the main idea and new information of the text. A graphic would also help the student's brain to memorize the information and put on it on their long-term memory.

\section{CONCLUSIONS}

Based on the result of the data analysis, the researcher drew some major conclusions as follows: first, applying the Graphic Organizer reading strategy in reading lessons could improve students' reading comprehension achievement. The improvement has been shown by the significant increase in the students' scores after the treatment. The findings are in alignment with a number of the previous study on the effectiveness of the Graphic Organizer reading strategy that has been reviewed in the previous chapter.

Second, the Graphic Organizer reading strategy that was applied properly significantly improved the students reading comprehension. From the output of SPSS, the data showed that there was a significant improvement in students' reading comprehension achievement compared with the control class who was taught using conventional techniques. Graphic Organizer showed 11,04 point differences in the result between the experiment class and control class. In other words, students who applied the Graphic Organizer reading strategy get 11,04 points higher than the Conventional Strategy. 
The researcher examined in the classroom that the students in Graphic Organizer reading strategy became more familiar with way how to find the main idea and the important information correctly then finally improved their comprehension toward the text they read.

\section{REFERENCES}

Arikunto, S. (2012). Dasar-Dasar Evaluasi Pendidikan. Jakarta: Bumi Aksara.

Bethune, K \& Wood, C. (2013). Effects of Wh-Question Graphic Organizers on Reading Comprehension Skills of Students with Autism Spectrum Disorders. Education and Training in Autism and Developmental Disabilitites. 48. 236-244.

Catherine S. C.. (2002). Reading for Understanding: Toward an R\&D in Reading Comprehension. Arlington: RAND Education.

Lynn, J. \& Miranda, W. (2011). Effect of Graphic Organizer on the Reading Comprhension an English Language Learner with a Learning Disability. Second Language Studies in Fall, in 30 (1). 95-183.

Grabe, W. (2009). Reading in Second Language: Moving from Theory to Practice. New York: Cambridge University Press.

Harmer, J. (2011). The Practice of Language Teaching. $4^{\text {th }}$ ed. London: Pearson Longman. Hartoyo. 2011. Language Assessment. Semarang. Pelita Insani.

Jian, X \& William G. (2009). Building Reading Abilities with Graphic Organizers. In R. Cohen (Ed), Teaching Reading. Alexandria, V: TESOL.https://humboldtcollegehandbook.wikispaces.com/file/view/ Jiang_ Grabe Building+Reading+Abilities. P.5-32. Assessed on. February, 12, 2014.

Lehr, F, Osborn, J, \& Hiebert, E. (2005). A Focus on Comprehension. California: PREL.

Michele H. (2002). Reading Comprehension: strategies for elementary and Secondary School students. Virginia: Lynchburg College.

Nuttal. C. (1996). Teaching Reading Skill in Foreign Languag. Great Britain: The Bath Press. Premalatah, R. \& Sam, P. (2013). Using Graphic Organizer to improve Reading on Comprehension Skill for the middle School ESL Student. English Language Teaching Canadian Center of Science and Education. 6(2). 23-35

Snow. C, \& Chair. (2002). Reading For Understanding: Toward an RnD Program in Reading Comprehension. Santa Monica: RAND.

Scoot, S. E. (2009). Knowledge for Teaching Reading Comprehension: Mapping Terrain. Arbor: ProQuest. LLC. 